\title{
Maternal and perinatal outcome of pregnancy in women with one previous caesarean section-a study at a tertiary care centre
}

\author{
Deepthi Venkatesh $^{1}$, Varun G. Huilgol ${ }^{2 *}$, Gopalkrishna B. Huilgol ${ }^{1}$
}

\begin{abstract}
${ }^{1}$ Department of Obstetrics and Gynecology, Bangalore Medical College and Research Institute, Bengaluru, Karnataka, India

${ }^{2}$ Senior Resident, Vardhaman Mahaveer Medical College and Safdarjung Hospital, New Delhi, India
\end{abstract}

Received: 29 September 2020

Revised: 06 November 2020

Accepted: 07 November 2020

\section{*Correspondence:}

Dr. Varun G. Huilgol,

E-mail: deepthivnktsh@gmail.com

Copyright: (C) the author(s), publisher and licensee Medip Academy. This is an open-access article distributed under the terms of the Creative Commons Attribution Non-Commercial License, which permits unrestricted non-commercial use, distribution, and reproduction in any medium, provided the original work is properly cited.

\begin{abstract}
Background: Increasing rates of primary caesarean section has led to an increased proportion of obstetric population with history of prior caesarean delivery. There is growing concern by obstetrician for optimizing the management of these high risk cases. The present study was undertaken to evaluate obstetric and fetal outcome of patients presenting at term with history of one previous LSCS.

Methods: This was a prospective hospital based observational study conducted at Vani Vilas Hospital and Bowring and Lady Curzon Hospital, Department of OBG, BMC and RI, Bangalore. The study included 300 patients who had undergone previous one LSCS with term pregnancy.

Results: Majority of patients, that is $186(62 \%)$ were in the age group of 21 to 25 years. Out of 300 patients, 94 $(31.33 \%)$ patients went for repeat LSCS without trial. $206(68.67 \%)$ patients were included in the trial of labour group, out of which 109 (52.9\%) patients had successful vaginal delivery. 97 (47.1\%) patients went for repeat LSCS in trial group due to various indications, commonest being scar tenderness.

Conclusions: Delivery of patients with previous caesarean section should always be conducted in a well-equipped hospital where facilities for immediate intervention are available if necessity arises. These patients should be counselled antenatally regarding institutional delivery, encouraging trial of labour after caesarean section in select group of patients with close fetal and maternal monitoring for early detection of complications and its management reduces maternal and perinatal mortality and morbidity.
\end{abstract}

Keywords: Maternal morbidity, Post caesarean pregnancy, Previous LSCS, VBAC

\section{INTRODUCTION}

Management of the woman who has undergone caesarean section has been a controversial topic for more than 100 years. By the beginning of $20^{\text {th }}$ century, caesarean section had become relatively safe. But as women survived the first operation and conceived again, they were now at risk for uterine rupture. This was because of the prevailing use of classical incision at that time. The inherent dangers of uterine rupture led to the dictum "once a caesarean, always a caesarean" by Cragin (1916). Later the introduction of Kerr's incision-a transverse low segment uterine incision changed this belief and gave rise to the concept of vaginal birth after caesarean. The introduction of Lower segment caesarean section (LSCS) gave a good and strong scar to the uterus, to hold and safely deliver a subsequent pregnancy. It is now safe to say "once a caesarean section, always a hospital delivery.

With the sky rocketing caesarean section rates an increasing number of women face the issue of mode of delivery in their current pregnancy. There are conflicting 
reports regarding the safety of a trial for vaginal birth after caesarean delivery (VBAC) in terms of uterine rupture, maternal and perinatal morbidity. Therefore a study is required to evaluate the maternal and fetal outcomes of patients presenting at term with a history of one previous lower segment caesarean section. No randomized controlled trials have compared the results of routine repeat caesarean section with those of planned vaginal birth for women who have had a previous caesarean section. ${ }^{2}$ In the absence of such trials, the best available data on the outcome of post caesarean pregnancy come from observational prospective studies.

The purpose of this study was to evaluate the maternal and fetal outcome of labour in cases of previous caesarean section in our teaching hospital.

In an appropriate clinical setting and properly selected group of women, vaginal delivery after caesarean section (VBAC) is safe and effective. ${ }^{1}$ Both attempting vaginal birth and opting for an elective repeat caesarean section are associated with different risk for the mother and newborn and deciding a delivery plan involves a difficulty weighing of those risks. ${ }^{3}$ A number of studies have compared the risks and benefits of a trial of labour with those of repeat caesarean section and have also demonstrated the increased risks associated with failed trial of labour. Incidence of primary caesarean section has increased multifold over the last 20 years. As a result, an increasing number of women face the issue of mode of delivery in their subsequent pregnancy. The rising rate of caesarean sections is a reason for immediate concern and deserves serious attention. ${ }^{1}$

The main aim of this study was to determine the outcome of pregnancy in women with prior caesarean section in relation to mode of delivery, maternal and perinatal complications.

\section{Aims and objectives of the study}

To assess: 1) Mode of delivery in women with one previous caesarean section. 2) Maternal outcome, morbidity and mortality (if associated) in terms of duration of hospital stay, wound infection, hysterectomy, scar dehiscence/rupture, ICU admission. 3) Perinatal outcome in terms of APGAR score at $1^{\text {st }}$ and $5^{\text {th }}$ minute, need for newborn resuscitation, admission to neonatal intensive care unit, perinatal mortality.

\section{METHODS}

\section{Source of data}

Women with one previous caesarean section admitted in Vani Vilas Hospital and Bowring and Lady Curzon Hospital, Department of OBG, Bangalore Medical College and Research Institute, Bangalore formed the subjects of the study.

\section{Methods of collection of data}

It was a hospital based observational study from January 2016 to December 2016 including in-patients at hospitals attached to Bangalore Medical College and Research Institute with a sample size of 300 .

\section{Inclusion criteria}

Pregnant women with one previous lower segment caesarean section with singleton pregnancy $\geq 37$ weeks period of gestation having vertex presentation and interpregnancy interval more than 18 months and non recurrent indication for previous caesarean section were included.

\section{Exclusion criteria}

Women with more than one previous caesarean section were excluded along with previous classical section or inverted " $T$ ", uterine scar. Women with previous hysterotomy or myomectomy, uterine rupture, intrauterine death, any fetal anomaly incompatible with life, fetal macrosomia, presence of contraindication to labour such as placenta previa or mal presentation were all excluded along with any medical complications such as hypertension, diabetes mellitus, anemia, cardiac disease.

\section{Methodology}

After obtaining clearance and approval from Institutional Ethical Committee, pregnant women with one previous caesarean section who were admitted in Vani Vilas Hospital and Bowring and Lady Curzon Hospital, Department of OBG, Bangalore Medical College and Research Institute, Bangalore from January 2016 to December 2016 were selected by simple random sampling after applying inclusion and exclusion criteria and included in the study.

Written informed consent was taken from all the patients included in the study. Demographic data was collected.

Detailed information about past obstetric history was noted including indication and place of previous caesarean section, any full term vaginal deliveries prior to, or following previous caesarean section, complications following previous caesarean section such as need for blood transfusion, foul smelling lochia, fever, wound and /or systemic infection requiring prolonged hospitalization.

A general physical and systemic examination was carried out followed by obstetric examination.

Outcome of present pregnancy in terms of mode of delivery, maternal outcome, morbidity and mortality (if associated) in terms of duration of hospital stay, requirement of blood transfusion, wound infection, 
hysterectomy, scar dehiscence/rupture, ICU admission was noted. Neonatal outcome was assessed in terms of APGAR score at $1^{\text {st }}$ and $5^{\text {th }}$ minute, need for NICU admission and the indication for the same and neonatal mortality. Data collected for the purpose of the study was recorded in the study proforma.

Statistical analysis: The data collected was analyzed statistically. The qualitative variables was expressed in percentage and continuous variables were measured and expressed using descriptive statistics. Graphical representation was used wherever necessary. The association between mode of delivery, maternal and perinatal outcome was assessed using chi-square test.

\section{RESULTS}

There were 15159 deliveries during the study period. Among them 4078 were caesarean deliveries. Among these patients 1152 patients were found to have one previous caesarean section. 300 patients were recruited from these 1152 patients with one previous LSCS, who fulfilled all the inclusion criteria.

Among 300 cases in the study group, $206(68.67 \%)$ patients were given trial of labour after patients fulfilled the criteria for trial of labour., ${ }^{4,5}$ Remaining 94 (31.33\%) patients were directly taken up for caesarean section either elective/emergency in view of various indications with scar tenderness, fetal distress being the commonest.

Table 1: Distribution of cases according to indications for primary caesarean section.

\begin{tabular}{|lll|}
\hline Indications & No. of cases & Percentage (\%) \\
\hline Fetal Distress & 123 & 41.0 \\
\hline CPD & 38 & 12.7 \\
\hline Oligohydramnios & 22 & 7.3 \\
\hline Malpresentation & 35 & 11.7 \\
\hline Non progress & 26 & 8.7 \\
\hline Failed induction & 42 & 14.0 \\
\hline APH & 09 & 3.0 \\
\hline Multiple pregnancy & 05 & 1.7 \\
\hline Total & 300 & 100 \\
\hline
\end{tabular}

Table 2: Distribution of cases according to mode of delivery in trial group $(n=206)$.

\begin{tabular}{|c|c|c|}
\hline Mode of delivery & No. of patients & Percentage (\%) \\
\hline $\begin{array}{l}\text { Spontaneous } \\
\text { vaginal delivery }\end{array}$ & 67 & 32.5 \\
\hline Repeat LSCS & 97 & 47.1 \\
\hline $\begin{array}{l}\text { Assisted vaginal } \\
\text { delivery }(n=42)\end{array}$ & 42 & 20.4 \\
\hline Vacuum & $40 / 42=95.2 \%$ & \\
\hline Forceps & $2 / 42=4.8 \%$ & \\
\hline Total & 206 & 100.0 \\
\hline
\end{tabular}

Table 3: Distribution of cases according to indication for LSCS non trial group.

\begin{tabular}{|llll|}
\hline $\begin{array}{l}\text { Mode of } \\
\text { delivery }\end{array}$ & No. of patients & $\begin{array}{l}\text { No. of } \\
\text { cases }\end{array}$ & $\begin{array}{l}\text { Percentage } \\
(\%)\end{array}$ \\
\hline $\begin{array}{l}\text { Elective } \\
\text { LSCS }\end{array}$ & Postdatism & 19 & 20.2 \\
\cline { 2 - 4 } & CPD & 12 & 12.7 \\
\hline \multirow{2}{*}{$\begin{array}{l}\text { Emergency } \\
\text { LSCS }\end{array}$} & $\begin{array}{l}\text { Not willing to } \\
\text { give consent }\end{array}$ & 09 & 9.57 \\
\cline { 2 - 4 } & Fetal distress & 21 & 22.3 \\
\cline { 2 - 4 } & Scar tenderness & 33 & 35.1 \\
\hline
\end{tabular}

Table 4: Indication for trial group.

\begin{tabular}{|lll|}
\hline Indication & No. of cases & Percentage (\%) \\
\hline Scar tenderness & 43 & 44.3 \\
\hline Fetal distress & 35 & 36.1 \\
\hline Failure to progress & 17 & 17.5 \\
\hline Threatened rupture & 02 & 2.1 \\
\hline Total & 97 & 100.0 \\
\hline
\end{tabular}

Table 5: Distribution of cases according to dilatation of cervix and its outcome in trial group.

\begin{tabular}{|llll|}
$\begin{array}{l}\text { Cervical } \\
\text { dilatation } \\
(\mathbf{c m})\end{array}$ & $\begin{array}{l}\text { Spontaneous } \\
\text { vaginal } \\
\text { delivery }\end{array}$ & $\begin{array}{l}\text { Instrumental } \\
\text { vaginal } \\
\text { delivery }\end{array}$ & $\begin{array}{l}\text { Repeat } \\
\text { LSCS }\end{array}$ \\
\hline$\leq \mathbf{3}$ & $03(4.5)$ & $04(9.5)$ & $58(59.8)$ \\
\hline $\mathbf{4 - 7}$ & $50(74.6)$ & $31(73.8)$ & $33(34.0)$ \\
\hline$\geq \mathbf{8}$ & $14(21)$ & $07(16.7)$ & $06(6.2)$ \\
\hline Total & $67(100.0)$ & $42(100.0)$ & $97(100.0)$ \\
\hline$\chi^{2}=68.65, \mathrm{p}<0.001$ & & \\
\hline
\end{tabular}

Statistical significance was noted in mode of delivery with dilatation of cervix ( $\mathrm{p}<0.001) .102$ patients delivered vaginally either spontaneously or with assistance when cervical dilatation was $\geq 4 \mathrm{~cm}$.

Table 6: Maternal morbidity in trial group.

\begin{tabular}{|lllll|} 
Complications & $\begin{array}{l}\text { VBAC } \\
(\mathbf{n}=109)\end{array}$ & $\begin{array}{l}\text { LSCS } \\
(\mathbf{n}=97)\end{array}$ & $\begin{array}{l}\text { Z } \\
\text { value }\end{array}$ & P value \\
\hline Pyrexia & $1(0.9)$ & $4(4.1)$ & 1.419 & $0.08(\mathrm{NS})$ \\
\hline Wound infection & - & $5(5.2)$ & 2.754 & $<0.003^{* *}$ \\
\hline UTI & - & $7(7.2)$ & 3.281 & $<0.005^{* *}$ \\
\hline PPH & $6(5.5)$ & $7(7.2)$ & 1.023 & $0.154(\mathrm{NS})$ \\
\hline Paralytic ileus & - & $2(2.1)$ & 1.725 & $0.033^{*}$ \\
\hline$* \mathrm{p}<0.05, * * \mathrm{p}<0.001$ & & & \\
\hline
\end{tabular}

Table 7: Mean duration of hospital stay.

\begin{tabular}{|llll|}
\hline No. of days & Non trial & VBAC & Failed TOLAC \\
\hline $\mathbf{2 - 4}$ & - & 105 & - \\
\hline $\mathbf{5 - 8}$ & 89 & 4 & 88 \\
\hline$>\mathbf{8}$ & 5 & - & 9 \\
\hline
\end{tabular}

$* \mathrm{p}<0.001$ 
Labour was augmented with oxytocin drip where ever necessary with careful monitoring.

Statistical significance was noted with regard to mean duration of hospital stay among VBAC and caesarean section group.

Table 8: Birth weight in study group.

\begin{tabular}{|lll|}
\hline Birth weight $(\mathrm{kg})$ & No. of cases & Percentage \\
\hline$\leq \mathbf{2 . 5}$ & 28 & 9.3 \\
\hline $\mathbf{2 . 6 - 3 . 0}$ & 240 & 80.0 \\
\hline $\mathbf{3 . 0}$ & 32 & 10.7 \\
\hline
\end{tabular}

Table 9: Neonatal resuscitation in study group.

\begin{tabular}{|llll|}
\hline & Non trial & VBAC & $\begin{array}{l}\text { Failed } \\
\text { TOLAC }\end{array}$ \\
\hline $\begin{array}{l}\text { Resuscitation } \\
\text { needed }\end{array}$ & $04(4.3)$ & $05(4.6)$ & $09(9.3)$ \\
\hline $\begin{array}{l}\text { Resuscitation } \\
\text { Not needed }\end{array}$ & $90(95.7)$ & $104(95.4)$ & $88(90.7) *$ \\
\hline Total & $94(100.0)$ & $109(100.0)$ & $97(100.0)$ \\
\hline
\end{tabular}

$\chi^{2}=2.74, \mathrm{P}>0.254 *$ One still birth

Table 10: Neonatal outcome and neonatal complications.

\begin{tabular}{|c|c|c|c|}
\hline & $\begin{array}{l}\text { Non trial } \\
\text { group }\end{array}$ & VBAC & $\begin{array}{l}\text { Failed } \\
\text { TOLAC }\end{array}$ \\
\hline Alive & $\begin{array}{l}94 \\
(100.0)\end{array}$ & $\begin{array}{l}109 \\
(100.0)\end{array}$ & $96(99.0)$ \\
\hline Still birth & - & - & $01(1.0)$ \\
\hline $\begin{array}{l}\text { Neonatal } \\
\text { complications }\end{array}$ & $\begin{array}{l}\text { Non trial } \\
(n=94)\end{array}$ & $\begin{array}{l}\text { VBAC } \\
(n=109)\end{array}$ & $\begin{array}{l}\text { Failed } \\
\text { TOLAC } \\
(\mathbf{n}=97)\end{array}$ \\
\hline Fever & - & - & $01(1.0)^{* *}$ \\
\hline Birth asphyxia & - & $02(1.9)$ & $01(91.0)$ \\
\hline Septicemia & - & - & $\begin{array}{l}01 \\
(1.0)^{* * *}\end{array}$ \\
\hline Hyperbilirubinemia & $03(3.2)$ & $02(1.9)$ & $04(4.1)$ \\
\hline No complications & $91(96.8)$ & $105(96.2)$ & $90(92.9)$ \\
\hline
\end{tabular}

Table 11: Distribution of cases according to APGAR at 5 minutes and NICU admission.

\begin{tabular}{|c|c|c|c|}
\hline APGAR & $\begin{array}{l}\text { Non trial } \\
(\mathrm{n}=94)\end{array}$ & $\begin{array}{l}\text { VBAC } \\
(n=109)\end{array}$ & $\begin{array}{l}\text { Failed TOLAC } * \\
(n=96)\end{array}$ \\
\hline$>8$ & $83(88.3)$ & $97(89.0)$ & $79(82.3)$ \\
\hline $7-8$ & $11(11.7)$ & $10(9.2)$ & $16(16.7)$ \\
\hline$\leq 6$ & - & $02(1.8)$ & $01(1.0)$ \\
\hline $\begin{array}{l}\text { NICU } \\
\text { admission }\end{array}$ & $\begin{array}{l}\text { Non trial } \\
(n=94)\end{array}$ & $\begin{array}{l}\text { VBAC } \\
(n=109)\end{array}$ & $\begin{array}{l}\text { Failed TOLAC* } \\
(n=96)\end{array}$ \\
\hline Yes & 4 & 07 & $13(14.5)^{* *}$ \\
\hline No & 90 & 102 & $83(86.5)^{* * *}$ \\
\hline
\end{tabular}

*1 still birth; **1 Died in NICU; *** 1 still birth
APGAR score of $>8$ was found in 176 neonates in trial group and 83 neonates in non-trial group.

\section{DISCUSSION}

There is wide spread public and professional concern about the increasing proportion of caesarean births worldwide. ${ }^{3}$ Increasing rates of primary caesarean section has led to an increased proportion of obstetric population with history of prior caesarean delivery. There are numerous studies done in India and other countries which suggest that, for carefully selected women with one previous caesarean section, a trial for vaginal delivery with close maternal and fetal monitoring is safe with a success rate of $60 \%-80 \% .^{6,7}$

There were 15159 deliveries during the study period. Among them 4078 were caesarean deliveries. Among these patients 1152 patients were found to have one previous caesarean section. 300 patients in the above group with term pregnancy were included in the study that satisfied the inclusion criteria.

Majority of the patients in the study group i.e. $186(62 \%)$ were in the age group of 21-25 years.

278 (92.67\%) patients were between 37-40 weeks of gestation.

Among 300 cases in the study group, 206 (68.67\%) patients were given trial of labour after patients fulfilled the criteria for trial of labour. Majority of the remaining $94(31.33 \%)$ patients were directly taken up for caesarean section either elective/emergency in view of various indications with scar tenderness, fetal distress being the commonest.

Among 206 patients who were given trial of labour, 109 $(52.9 \%)$ patients had successful vaginal delivery. Among these 109 patients with vaginal delivery, 67 (32.5\%) patients had spontaneous vaginal delivery, 42 (20.4\%) patients had assisted vaginal delivery with vacuum and forceps. Majority of patients in the assisted vaginal delivery group i.e. $40(95.2 \%)$ were delivered with vacuum. In $2(4.8 \%)$ patients, forceps was applied due to fetal distress.

109 (52.9\%) patients had successful vaginal delivery in the study group which was comparable with other studies.

Table 12: Comparison of mode of delivery.

\begin{tabular}{|c|c|c|c|}
\hline $\begin{array}{l}\text { Mode of } \\
\text { delivery }\end{array}$ & Study group & $\begin{array}{l}\text { Anagha } \\
\text { et } \mathbf{a l}^{8}\end{array}$ & Singh et al ${ }^{9}$ \\
\hline VBAC & $52.90 \%$ & $46.70 \%$ & $61 \%$ \\
\hline Repeat LSCS & $47.10 \%$ & $53.30 \%$ & $39 \%$ \\
\hline
\end{tabular}

Intraoperatively $22 \%$ of cases had adhesions in study group as compared to $26.92 \%$ in Singh et al study. ${ }^{9}$ 
Scar dehiscence was noted in $3.7 \%$ of cases in study group as compared to $7.69 \%$ in Singh et al study. ${ }^{9}$

There were $2(1 \%)$ patients with uterine scar rupture and one case of bladder injury which were repaired. Incidence of scar rupture was $1 \%$ in the study group and $1 \%$ in Singh et al study. ${ }^{9}$

The maternal morbidity in terms of pyrexia, wound infection, UTI were found to be higher in caesarean group compared to vaginal delivery group which was statistically significant.

There was no statistical significance in APGAR score and need for neonatal resuscitation in VBAC and caesarean group. There was one still birth in patient with rupture uterus and one neonatal death on day 4 in NICU, both in failed trial of labour group. The hospital stay of patients who had vaginal delivery was shorter which was statistically significant compared to caesarean group.

The limitation of this study was the patients who were postdated and not in labour were directly taken for repeat LSCS as there was no policy for induction in such cases at our institution in view of higher incidence of uterine rupture with use on agents for induction of labour in such cases. ${ }^{10}$

\section{CONCLUSION}

Management of patients with previous caesarean section is one of the controversial issues in obstetrics, which has gained immense importance in present era due to increase in the proportion of patients with previous caesarean section.

\section{Recommendations}

It is necessary for health care personnel to provide proper antenatal counselling regarding need for institutional delivery and option of VBAC. Correct analysis of prior indication for caesarean section helps to classify the patients for elective caesarean delivery or trial of vaginal delivery. A well-defined management protocol for patients selected for trial of labour should be instituted. They should be counselled about the benefits and risks (intrapartum emergencies like scar dehiscence, uterine rupture) involved. A routine elective caesarean section is associated with more morbidity. Hence, whenever feasible vaginal birth should be encouraged. Encouraging trial of labour after caesarean section helps to reduce the complications associated with anaesthesia, surgery and post-operative complications. It also reduces the hospital stay. Proper selection of patients with close fetal and maternal surveillance for early detection of complications is advised. Delivery of patients with previous caesarean section should be done in a well-equipped hospital, where facilities for immediate intervention are available if necessity arises so as to reduce/prevent maternal and perinatal morbidity and mortality.

This study helps us understand that trial of labour is possible in previous LSCS cases at tertiary centres where most of the cases are referred from elsewhere, with careful selection and monitoring. Successful VBAC benefits both mother and healthcare establishment by reducing maternal morbidity, decreasing duration of hospital stay with faster recovery and decreasing the burden of cases on existing healthcare staff and the government.

\section{Funding: No funding sources}

Conflict of interest: None declared

Ethical approval: The study was approved by the Institutional Ethics Committee

\section{REFERENCES}

1. Mukherjee SN. Rising cesarean section rate. J Obstet Gynecol India. 2006;56:298-300.

2. Dodd JM, Crowther CA, Huertas E, Guise JM, Horey D. Planned elective repeat caesarean section versus planned vaginal birth for women with a previous caesarean birth. Cochrane Database Syst Rev. 2013;12.

3. Parliamentary Office of Science and Technology. Caesarean sections. Post Note. 2002;184:14.

4. ACOG Practice Bulletin. Vaginal birth after previous caesarean delivery. Clinical Management Guidelines for Obstetrician-Gynaecologists; 2004:54.

5. Royal College of Obstetricians and Gynaecologists (RCOG). Birth after previous caesarean section. Green-Top Guideline No. 45. London: RCOG; 2007.

6. Chhabra S, Arora G. Delivery in women with previous caesarean section. J Obstet Gynaecol India. 2006;56:304-7.

7. Vardhan S, Behera RC, Sandhu GS, Singh A, Bandhu HC. Vaginal birth after caesarean delivery. J Obstet Gynaecol India. 2006;56:320-3.

8. Anagha A, Jinturkar DD. Study of obstetric and fetal outcome of post caesarean section pregnancy at tertiary care center. Int J Recent Trends Sci Tech. 2014;10(3):530-7.

9. Singh S, Dhama V, Chaudhary R, Karya U, Nanda $\mathrm{K}$. Maternal and fetal outcome in pregnant women with previous one lower segment cesarean section. Int J Reprod Contracept Obstet Gynecol. 2016;5(11):3816.

10. Plaut MM, Schwartz ML, Lubarsky SL. Uterine rupture associated with the use of misoprostol in the gravid patient with a previous cesarean section. Am J Obstet Gynecol. 1999;180(6):1535-4.

Cite this article as: Venkatesh D, Huilgol VG, Huilgol GB. Maternal and perinatal outcome of pregnancy in women with one previous caesarean section-a study at a tertiary care centre. Int J Reprod Contracept Obstet Gynecol 2020;9:5055-9. 